\title{
Effects of Foreign Language Anxiety and Perceived Competence on Learning Strategy Use
}

\author{
Hui-ju Liu ${ }^{1}$ \\ ${ }^{1}$ Department of English, Da-Yeh University, Taiwan \\ Correspondence: Hui-ju Liu, Department of English, Da-Yeh University, Taiwan. E-mail: \\ carlota@mail.dyu.edu.tw
}

Received: December 28, 2012 Accepted: February 3, 2013 Online Published: May 17, 2013

doi:10.5539/ijel.v3n3p76 URL: http://dx.doi.org/10.5539/ijel.v3n3p76

\begin{abstract}
This study intends to provide a wider range of insights into the strategy use by EFL learners with different levels of language anxiety and self-rated competence. The participants included university freshmen sampled from different English proficiency levels. The findings revealed that the most frequently used strategy category among low-anxiety students was metacognitive. Similarly, metacognitive strategies, followed by cognitive and compensation strategies, were used most frequently by students with the highest level of self-rated proficiency. Social strategies were the least used, regardless of anxiety or self-rated proficiency level. Language anxiety seems to have a greater influence on the strategy use frequency rather than on strategy choice. The results demonstrated significant effects of language anxiety and perceived competence on learning strategy use. In addition, self-perceived competence was shown to have a stronger link to strategy use than the learner's actual language proficiency. Among anxiety and perceived and actual competence, perceived competence was identified to be the best predictor of strategy use. Nonetheless, the effect of anxiety on language learning cannot be ignored as it was found to have a similar level of association with strategy use as actual proficiency did, although its effect was significantly negative.
\end{abstract}

Keywords: language anxiety, language learning strategy, strategy use frequency, self-perceived competence, language proficiency

\section{Introduction}

Krashen (1987) suggested that most affective variables in language acquisition research can be placed into one of three categories: motivation, anxiety, and self-confidence. According to the Affective Filter hypothesis he proposed, in addition to "comprehensible input," a low or weak affective filter is essential to allow input into a second language acquisition system (p. 32). To lower the affective filter, teachers must help students lower their anxiety levels (Krashen, 1989). Additionally, Dörnyei (2001) indicated that lowering student language anxiety, in addition to teaching useful learning strategies, is one of the many strategies that can promote motivation in the classroom. According to Dörnyei, the application of these two motivational strategies can benefit learners' self-confidence and eventually help improve their learning effectiveness.

Oxford and Ehrman (1995) noted that "learning strategy users were highly persistent, strongly motivated, and oriented toward systematic planning" (p. 378). The frequency of strategy use has been found in a number of studies to be positively associated with ESL/EFL learners' learning motivation (Lan \& Oxford, 2003; MacIntyre \& Noels, 1996; Oxford \& Nyikos, 1989; Wharton, 2000), beliefs about language learning (Yang,1992, 1999; Yin, 2008), and language performance (Dreyer \& Oxford, 1996; Green \& Oxford, 1995; Griffiths, 2003; Lai, 2009; Magogwe \& Oliver, 2007; Peacock \& Ho, 2003; Yilmaz, 2010). Nevertheless, there is still very limited investigation into the strategy use of EFL learners in relation to language anxiety and self-rated proficiency. This study intends, therefore, to contribute to the understanding of the relationship between these variables and provide useful implications for language instructors and researchers in this area.

\subsection{Language Anxiety}

MacIntyre and Gardner (1994) defined language anxiety as "the feeling of tension and apprehension specifically associated with second language contexts, including speaking, listening, and learning” (p. 284). For decades, researchers have treated language anxiety as a separate and specific form of anxiety experienced in the course of 
learning a different target language (Gregersen \& Horwitz, 2002; Horwitz, Horwitz, \& Cope, 1986; MacIntyre \& Gardner, 1989, 1991a, 1991b). Regardless of the target language, similar conclusions concerning the prevalence of language anxiety have been made by researchers in studies undertaken in Western foreign language classrooms (Aida, 1994; Horwitz, et al., 1986; MacIntyre \& Gardner, 1994; Marcos-Llinás \& Garau, 2009; Saito, Horwitz, \& Garza, 1999; Wu, 2011) and in the Asian EFL setting of Japan (Williams \& Andrade, 2008) and Taiwan (Chan \& Wu, 2004; Jen, 2003; Liu, 2010b). Horwitz et al. (1986) identified three important constructs relevant to anxiety in the foreign language classroom: communication apprehension, fear of negative evaluation, and test anxiety. Communication apprehension is characterized as one's discomfort in communicating with others. Fear of negative evaluation is defined as apprehension about what others will say or feel about one's performance. Test anxiety involves worry over one's performance in an evaluative situation.

Many prior studies have revealed that levels of language anxiety can be affected by various factors. In Saito, Horwitz, and Garza's (1999) study, levels of specific reading anxiety varied according to the target language, French, Japanese, or Russian. Learners of Japanese were found to experience the highest level of anxiety, followed by learners of French and Russian. In addition, levels of reading anxiety varied according to the perceived difficulty level of the target language. In Kim's (2009) study, levels of general type of language anxiety differed in different classroom contexts. A higher level of anxiety was identified in the classroom of a conversation course when compared to that in a reading course. Marcos-Llinás and Garau (2009) pointed out that levels of anxiety varied across student language proficiency levels; however, it should be noted that their findings suggested that more advanced learners scored higher on the language anxiety scale than their counterparts. Based on a review of previous literature, Marcos-Llinás and Garau further summarized five types of factors linked to language anxiety: behavioral, cognitive, psycholinguistic, physical, and sociolinguistic factors.

As the majority of previous studies have shown an inverse relationship between language anxiety and language performance (MacIntyre, Noels, Clément, 1997; Marcos-Llinás \& Garau, 2009; Onwuegbuzie, Bailey, \& Daley, 1997; Phillips, 1992; Saito \& Samimy, 1996; Sánchez-Herrero \& Sánchez, 1992; Wang, 2010; Wei, 2007), a number of studies have explored the sources that lead to language anxiety (Oxford, 1999; Onwuegbuzie, Bailey, \& Daley, 1999; Yan \& Detaramani, 2008; Young, 1991). One example is Cheng's (2004) study of the sources of specific-writing-skill anxiety among Taiwanese EFL participants. In the investigation, Cheng categorized the sources into four types: instructional practices, personal beliefs about writing and learning to write, low self-confidence, and threats of interpersonal evaluation. Young (1991) classified the sources of general language anxiety into several aspects: personal and interpersonal anxieties, learner and instructor beliefs about language learning, instructor-learner interactions, classroom procedures, and language testing. For instance, personal and interpersonal anxieties may stem from problems such as low self-esteem, competitiveness, communication apprehension, and self-perceived low competence (Horwitz et al., 1986; MacIntyre, 1999; Young, 1990, 1999). Young posited that some of these sources may be interrelated. As Horwitz et al. (1986) concluded, as long as there is evaluation involved in foreign language learning, anxiety will continue to exist.

\subsection{Language Learning Strategy}

Language learning strategies are defined as "specific actions or techniques that students use, often intentionally, to improve their progress in developing L2 skills" (Green \& Oxford, 1995, p.262). Research on language learning strategies has undergone considerable growth since about three decades ago (Chamot, 2005; Macaro, 2006). Rubin (1975) was the first to notice strategies employed by good language learners and described them as making guesses intelligently, being willing to make mistakes, taking advantage of opportunities to practice, monitoring one's own speech, and having a strong motive to communicate. Griffiths (2003) later identified 19 "plus" strategies used by students of higher language proficiency level (p.376). Oxford and Ehrman (1995) maintained that good language learners should try to adjust their strategy use on the basis of their individual needs and requirements. Along with various learner characteristics such as gender, language aptitude, personality, and motivation, learning strategies have gained special attention since they not only can be used to assist language learning but also are teachable (Chamot, 2005; Dreyer \& Oxford, 1996; Hsiao \& Oxford, 2002; Lai, 2009; MacIntyre \& Noels, 1996; McMullen, 2009; Oxford, 1990; Oxford \& Ehrman, 1995; Oxford \& Nyikos, 1989).

The most widely recognized classification of language learning strategies is the taxonomy proposed by Oxford (1990). In her Strategies Inventory for Language Learning (SILL), strategies are comprised of two major classes: direct and indirect strategies. Direct strategies include memory, cognitive, and compensation strategies, while indirect strategies are composed of metacognitive, affective, and social strategies. Table 1 presents a total of 19 strategy sets further broken down by Oxford (1990). 
Table 1. Strategy system comprised of two classes, six groups, and 19 sets (Oxford, 1990, p. 17)

\begin{tabular}{|c|c|c|c|}
\hline \multicolumn{2}{|r|}{ Direct Strategies } & \multicolumn{2}{|c|}{ Indirect Strategies } \\
\hline $\begin{array}{l}\text { Memory } \\
\text { Strategies }\end{array}$ & $\begin{array}{ll}\text { 1. } & \text { Creating mental linkages } \\
\text { 2. Applying images and sounds } \\
\text { 3. Reviewing well } \\
\text { 4. Employing action }\end{array}$ & $\begin{array}{l}\text { Metacognitive } \\
\text { Strategies }\end{array}$ & 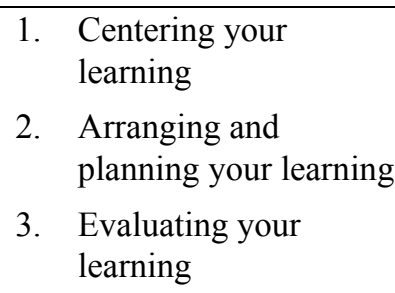 \\
\hline $\begin{array}{l}\text { Cognitive } \\
\text { Strategies }\end{array}$ & 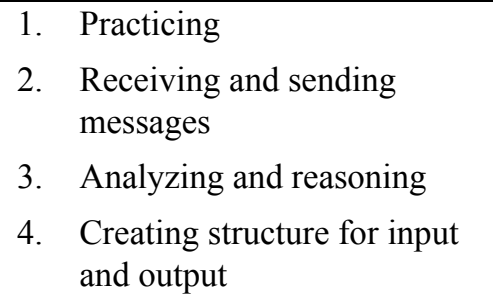 & $\begin{array}{l}\text { Affective } \\
\text { Strategies }\end{array}$ & $\begin{array}{l}\text { 1. Lowering your anxiety } \\
\text { 2. Encouraging yourself } \\
\text { 3. Taking your emotional } \\
\text { temperature }\end{array}$ \\
\hline $\begin{array}{l}\text { Compensation } \\
\text { Strategies }\end{array}$ & $\begin{array}{l}\text { 1. Guessing intelligently } \\
\text { 2. Overcoming limitations in } \\
\text { speaking and writing }\end{array}$ & $\begin{array}{l}\text { Social } \\
\text { Strategies }\end{array}$ & $\begin{array}{l}\text { 1. Asking questions } \\
\text { 2. Cooperating with } \\
\text { others } \\
\text { 3. Empathizing with } \\
\text { others }\end{array}$ \\
\hline
\end{tabular}

Lan and Oxford (2003) investigated strategy use among elementary school students and identified the five least and most frequently used individual strategies in the Taiwanese EFL setting. For all of the six types of strategies classified by Oxford, their usage was in the "medium-use range," with compensation and affective strategies used most frequently by young children (Lan and Oxford, 2003, p. 355). Strategy use was also found to be significantly related to gender, learner language proficiency, and degree of liking English. Degree of liking English, which was a sign of motivation according to the researchers, turned out to have the strongest effect on strategy use.

Sheu (2009) examined the strategy use of university freshmen in a technological university by administering a Chinese version of Oxford's (1990) SILL adapted by Yang (1992). Similar to the findings of many previous studies, with the exception of compensation strategies, females had a significantly higher use of learning strategies than males in all five categories. The most frequently used category of strategies by these EFL students was compensation strategies, the least frequently used being cognitive strategies. The findings showed a rather low use of strategies among the subjects; however, there were still significant differences in strategy use among students of various proficiency levels. Students in groups with a higher proficiency level and with a major in humanities/social sciences were both found to use language learning strategies more frequently.

Chen and Jonas (2009) examined the use of strategies among college students and found a medium to low level of strategy use, with metacognitive strategies used most frequently. Similary, Chen (2007) reported that metacognitive was the most frequently used category of strategies among college students in Taiwan, followed by cognitive and compensation strategies; memory was the least used category of strategies. In addition, language proficiency was found to be positively related to language learning strategies. More strategies were used by more proficient college learners. Chen's findings were later supported by Lai (2009).

Lee and Oxford (2008) claimed that strategy awareness has a significant effect on strategy use; in fact, it is the best predictor of strategy use, followed by self-rated proficiency, importance of English, and education level. Language teachers should help students develop strategy awareness and provide instruction that helps them learn how to use appropriate and effective learning strategies.

\subsection{Research Questions}

According to Yan and Horwitz's (2008) interviews of Chinese EFL students, many of them were concerned about their "inability to find effective language learning strategies" (p. 164). As Nyikos and Oxford (1993) noted, language instruction has shifted from a teacher-centered model towards a more leaner-centered approach. It is 
imperative for students to learn to become more active and apply strategies more frequently during the process of acquiring a foreign language. The aim of this study, therefore, is to provide more insight into the language learning strategy use (LLSU) of EFL learners, specifically its relations to foreign language anxiety and self-rated language proficiency, since both these variables can have some important effects on leaner motivation (Crookes \& Schmidt, 1991; Liu, 2010a). The following research questions are addressed:

1. What is the general profile of LLSU by students with varying degrees of anxiety levels?

2. What is the general profile of LLSU by students with varying self-perceived ability levels?

3. Is the effect of anxiety on LLSU significant among students in the EFL classroom?

4. Is the effect of self-perceived competence on LLSU significant among students in the EFL classroom?

5. Among learner anxiety and self-perceived and actual language proficiency, which one is a stronger predictor of LLSU?

\section{Method}

\subsection{Participants}

Participants of this study included 142 students, $46.5 \%$ males and $53.5 \%$ females, all non-English majors enrolled in required English four-skill classes at a university in central Taiwan (see Table 2). As soon as they entered school, they were homogeneously grouped into three proficiency levels for English instruction. The sample was composed of two classes of students from each proficiency level. At the time the data collection procedure was undertaken, they were at the beginning of their first academic year.

Table 2. Number of male and female participants in each ability level

\begin{tabular}{lllll}
\hline & Basic & Intermediate & Advanced & Total \\
\hline Male & 24 & 28 & 14 & 66 \\
Female & 18 & 22 & 36 & 76 \\
Total & 42 & 50 & 50 & 142 \\
\hline
\end{tabular}

For statistical analyses, students were divided into three groups based on their total anxiety scores (see Table 3). Students with anxiety scores in the bottom $25 \%$ of the overall score distribution were assigned to the low-anxiety group, while those with scores in the top $25 \%$ were assigned to the high-anxiety group. In addition, students were asked to evaluate their own language proficiency by selecting an option on a scale ranging from 1 (extremely bad) to 6 (extremely bad). On this scale, rating "1" was selected by 27 students (19\%), "2" by 40 (28.2\%), "3" by $57(40.1 \%)$, and " 4 " by 17 students (12\%). The rating " 5 " was selected by only one student, and was therefore combined with the group of students at level four.

Table 3. Descriptive statistics of subjects with different degrees of language anxiety

\begin{tabular}{lllll}
\hline Level & Number & Percentage & Range of Scores & Mean \\
\hline Low-Anxiety & 34 & 23.9 & $78-123$ & 106.56 \\
Mid-Anxiety & 73 & 51.4 & $124-155$ & 139.34 \\
High-Anxiety & 35 & 24.6 & $156-189$ & 167.24 \\
\hline
\end{tabular}

\subsection{Instrument}

To measure students' LLSU, Oxford's (1990) SILL was adapted and translated into a Chinese version for the current study, consisting of 50 items classified by Oxford into six categories of strategies for language learning in the four skills. All the items were graded on a Likert-type scale, ranging from 1 to 5 ( $1=$ never, $2=$ seldom, 3 = sometimes, 4 = usually, and 5 = always). The six categories of strategies included memory (items 1-9), cognitive (items 10-23), compensation (items 24-29), metacognitive (items 30-38), affective (items 39-44), and social strategies (items 45-50). The SILL has had a Cronbach alpha reliability coefficient ranging from 0.89 to 0.98 in various studies (Griffiths, 2003). The internal-consistency reliability index for this scale was .94 in this study. 
Language anxiety of the participants was assessed by the instrument developed by Horwitz, Horwitz, and Cope (1986), The Foreign Language Classroom Anxiety Scale (FLCAS), which was translated into Chinese for use in the Taiwanese EFL setting. The 33-item instrument, scored on a 6-point Likert scale, achieved an alpha coefficient of .93. The response format of the scale ranged from strongly disagree (1) to strongly agree (6).

The intermediate level General English Proficiency Test (GEPT), a widely and well recognized English proficiency test developed by the Taiwanese Language Training and Testing Center, was used as the instrument to measure the participants' English ability. For the present study, students were administered both a 40 -item GEPT reading test and a 45 -item GEPT listening test. Their actual English proficiency was obtained by adding their scores from the 85 test items.

\subsection{Data Analysis}

Before any statistical analysis was conducted, some negatively-worded items in the anxiety questionnaire were reversely scored. To understand the frequency of strategy use by students with varying anxiety and self-perceived ability levels, means of the six strategy category scores were computed and examined. Multivariate analysis of variance (MANOVA) was then performed to analyze the effects of anxiety and self-perceived academic competence on LLSU. Finally, in order to ascertain which of the three variables - anxiety, self-perceived and actual language proficiency - is the strongest predictor of LLSU, a stepwise regression analysis was performed on the data. Pearson product-moment correlation coefficients for each pair of the studied variables were also calculated to gain a better understanding of the relationships among these variables.

\section{Results and Discussion}

To investigate the use of learning strategies among students prone to language anxiety, means of the overall strategy use and six specific strategy category scores were calculated, and the results of which are presented in Table 4. According to the criterion of LLSU frequency set by Oxford (1990), the mean scores for overall strategy use by those in the three different anxiety-level groups were all in a medium range. However, as demonstrated by the findings in the present research, learners who experienced lower anxiety exhibited more frequent use of learning strategies. The most frequently used category of strategies for the low-anxiety group was metacognitive, followed by compensation and cognitive. Similarly, the top three categories of strategies used most frequently by those in the middle- and high-anxiety groups included the three above-mentioned types, although compensation rather than metacognitive strategies were the one used most frequently. It is also noteworthy that while Chen (2007) found that memory was the least used category of strategies by college students in Taiwan, the present findings demonstrated that social strategies were the least used, regardless of student anxiety or perceived ability levels. This result may be due to the limited exposure to the target language or a general lack of confidence in speaking English among the participants.

The means of LLSU by students grouped into four levels according to self-perceived language competence are reported in Table 5. The findings illustrated that when students had higher ratings in academic performance, their LLSU scores were also higher; that is, students who perceive themselves as more competent learners tend to apply learning strategies more frequently during the language acquisition process. While the students from both level 1 (mean $=2.29)$ and level $2($ mean $=2.48)$ showed low use of learning strategies, level 3 students exhibited medium use (mean $=2.95)$ and level 4 students high use (mean $=3.52)$. The most frequently used strategy type by students from level 4 was metacognitive, followed by cognitive and compensation, all in the high-use range. The ranking order of strategy categories by students at this level was consistent with the findings of Chen (2007). As to students with the lowest perceived proficiency level, compensation strategies were employed most often, although strategy use frequency was only in the medium range. Means of strategies in the other categories by students at this level were all in the low-frequency range. Overall, the results supported previous findings that metacognitive, cognitive, and compensation strategies were the three most often used strategies by college students in Taiwan (Chen, 2007; Lai, 2009); however, social strategies, instead of memory strategies, were the least used. 
Table 4. Means of LLSU by students with varying degrees of language anxiety

\begin{tabular}{|c|c|c|c|c|c|c|}
\hline \multirow[t]{2}{*}{ Strategy Category } & \multicolumn{2}{|c|}{ Low-Anxiety } & \multicolumn{2}{|c|}{ Mid-Anxiety } & \multicolumn{2}{|c|}{ High-Anxiety } \\
\hline & Rank Order & Mean & Rank Order & Mean & Rank Order & Mean \\
\hline Memory & 5 & 3.05 & 5 & 2.64 & 4 & 2.44 \\
\hline Cognitive & 3 & 3.19 & 2 & 2.76 & 3 & 2.58 \\
\hline Compensation & 2 & 3.23 & 1 & 2.84 & 1 & 2.83 \\
\hline Metacognitive & 1 & 3.25 & 2 & 2.76 & 2 & 2.61 \\
\hline Affective & 4 & 3.07 & 4 & 2.69 & 5 & 2.42 \\
\hline Social & 6 & 3.00 & 6 & 2.45 & 6 & 2.32 \\
\hline Overall & & 3.14 & & 2.70 & & 2.54 \\
\hline
\end{tabular}

Table 5. Means of LLSU by students with varying self-perceived ability levels

\begin{tabular}{|c|c|c|c|c|c|c|c|c|}
\hline \multirow[t]{2}{*}{ Strategy Category } & \multicolumn{2}{|c|}{ Level 1} & \multicolumn{2}{|c|}{ Level 2} & \multicolumn{2}{|c|}{ Level 3} & \multicolumn{2}{|c|}{ Level 4} \\
\hline & Rank & Mean & Rank & Mean & Rank & Mean & Rank & Mean \\
\hline Memory & 5 & 2.23 & 5 & 2.39 & 5 & 2.88 & 4 & 3.40 \\
\hline Cognitive & 3 & 2.30 & 3 & 2.54 & 3 & 2.99 & 2 & 3.64 \\
\hline Compensation & 1 & 2.56 & 1 & 2.65 & 1 & 3.07 & 3 & 3.63 \\
\hline Metacognitive & 3 & 2.30 & 2 & 2.55 & 2 & 3.03 & 1 & 3.66 \\
\hline Affective & 2 & 2.34 & 4 & 2.41 & 4 & 2.91 & 5 & 3.31 \\
\hline Social & 6 & 2.01 & 6 & 2.25 & 6 & 2.77 & 6 & 3.28 \\
\hline Overall & & 2.29 & & 2.48 & & 2.95 & & 3.52 \\
\hline
\end{tabular}

To ascertain whether the effect of anxiety on EFL student LLSU is significant, MANOVA was conducted to analyze the data. As the findings in Table 6 indicated, anxiety has a significant effect on LLSU, whether for use of strategies in individual categories or in overall strategy use. The Scheffe follow-up test results established that students classified in the high-anxiety level had significantly lower strategy use than students in other anxiety levels. The differences in the frequency of LLSU between students in the low- and mid-anxiety levels were found to be non-significant.

Table 6. MANOVA test results of differences in LLSU by students at different degrees of language anxiety

\begin{tabular}{lllllll}
\hline Source & Dependent Variable & SS & df & MS & F & Sig. \\
\hline Anxiety & Memory & 6.82 & 2 & 3.41 & 8.97 & $.000^{* *}$ \\
& Cognitive & 6.75 & 2 & 3.37 & 9.40 & $.000^{* *}$ \\
& Compensation & 4.05 & 2 & 2.03 & 4.76 & $.010^{*}$ \\
& Metacognitive & 7.88 & 2 & 3.94 & 8.53 & $.000^{* *}$ \\
& Affective & 7.33 & 2 & 3.66 & 8.88 & $.000^{* *}$ \\
& Social & 9.44 & 2 & 4.72 & 9.33 & $.000^{* *}$ \\
& Overall & 6.85 & 2 & 3.43 & 10.87 & $.000^{* *}$ \\
\hline$* p<.05 ; * *$ & $p<.01$ & & & & &
\end{tabular}

Consistent results were also found by conducting MANOVA on student LLSU scores with self-perceived ability 
level as the independent variable (see Table 7). The follow-up test revealed that students with the highest level of perceived proficiency had significantly higher strategy use frequency than those at other proficiency levels, with an exception in the use of affective strategies. The medium usage of affective learning strategies by students in perceived ability levels 3 and 4 was not significantly different. It is particular noteworthy that based on Oxford's (1990) criterion, learners who had the highest ratings of their own language proficiency belonged to the only group that had an average high use in overall strategy use. The results supported Oxford and Nyikos's (1989) findings that self-evaluation of proficiency may have an influential effect on strategy use.

Table 7. MANOVA test results of differences in LLSU by students with different self-perceived ability levels

\begin{tabular}{lllllll}
\hline Source & Dependent Variable & SS & df & MS & F & Sig. \\
\hline Self-Perception & Memory & 20.26 & 3 & 6.75 & 23.77 & $.000^{* *}$ \\
& Cognitive & 23.66 & 3 & 7.89 & 33.29 & $.000^{* *}$ \\
Compensation & 16.41 & 3 & 5.47 & 16.20 & $.000^{* *}$ \\
Metacognitive & 24.65 & 3 & 8.22 & 24.06 & $.000^{* *}$ \\
& Affective & 15.76 & 3 & 5.25 & 14.86 & $.000^{* *}$ \\
& Social & 23.15 & 3 & 7.72 & 18.87 & $.000^{* *}$ \\
& Overall & 21.10 & 3 & 7.03 & 33.08 & $.000^{* *}$ \\
\hline
\end{tabular}

Note. Self-Perception $=$ Self-Perceived Ability Level

$* p<.05 ; * * p<.01$

To gain more insight into the relations between LLSU, anxiety, and language proficiency, multiple regression analysis using the stepwise method was performed on the data. In addition to language anxiety and self-perceived competence, the independent variables, i.e., potential predictors of LLSU, used in the analysis also included actual language proficiency. As presented in Table 8, self-perception of language competence was the only predictor entered into the regression model, accounting for about $40 \%$ of the variance in LLSU all by itself. Both anxiety and actual language proficiency did not contribute significantly to the prediction of LLSU with the presence of learners' perceived competence in the regression model. To better understand the results, Pearson product-moment correlations among these variables were also calculated, the results being reported in Table 9. There is no doubt that self-perceived ability was the first variable entered into the regression model since it had the strongest link with LLSU (.634). Although language anxiety and actual language proficiency were significantly correlated with LLSU (-.434 and .454, respectively), they also had a relatively strong relation with self-perceived competence (-.649 and .683 , respective). Thus, they made little contribution to the prediction of LLSU when perceived competence was already selected in the statistical analysis. The results that language anxiety had a stronger association with perceived proficiency than with actual proficiency were in agreement with MacIntyre, Noels, and Clément's (1997) findings that perceived competence play an influential role in affecting language anxiety and actual performance.

Table 8. Results of the multiple regression model for predicting frequency of strategy use

\begin{tabular}{llllll}
\hline Variable & Regression Coefficient & Standard error & Beta & $t$ & $p$ \\
\hline (Constant) & 88.44 & 5.55 & & 15.94 & $.000^{* *}$ \\
Self-Perception & 20.06 & 2.08 & .63 & 9.64 & $.000^{* *}$ \\
\hline
\end{tabular}

Model: $R^{2}=.402 ;$ Adjusted $R^{2}=.398 ; \mathrm{F}(1,138)=92.87 ; * * p<.01$ 
Table 9. Pearson correlations between strategy use, language anxiety, self-perceived ability, and actual language proficiency

\begin{tabular}{lllllllllll}
\hline Variable & 1 & 2 & 3 & 4 & 5 & 6 & 7 & 8 & 9 & 10 \\
\hline 1 Strategy & - & & & & & & & & \\
2 Memory & $.875^{* *}$ & - & & & & & & & \\
3 Cognitive & $.953^{* *}$ & $.813^{* *}$ & - & & & & & & \\
4 Compensation & $.805^{* *}$ & $.631^{* *}$ & $.768^{* *}$ & - & & & & & \\
5 Metacognitive & $.922^{* *}$ & $.748^{* *}$ & $.849^{* *}$ & $.702^{* *}$ & - & & & & \\
6 Affective & $.834^{* *}$ & $.716^{* *}$ & $.727^{* *}$ & $.619^{* *}$ & $.743^{* *}$ & - & & & \\
7 Social & $.851^{* *}$ & $.671^{* *}$ & $.763^{* *}$ & $.613^{* *}$ & $.787^{* *}$ & $.697^{* *}$ & - & & \\
8 Anxiety & $-.434^{* *}$ & $-.376^{* *}$ & $-.415^{* *}$ & $-.296^{* *}$ & $-.398^{* *}$ & $-.367^{* *}$ & $-.396^{* *}$ & - & \\
9 Self-Perception & $.634^{* *}$ & $.549^{* *}$ & $.635^{* *}$ & $.490^{* *}$ & $.567^{* *}$ & $.478^{* *}$ & $.535^{* *}$ & $-.649^{* *}$ & - \\
10 Actual & $.454^{* *}$ & $.337^{* *}$ & $.474^{* *}$ & $.355^{* *}$ & $.404^{* *}$ & $.341^{* *}$ & $.420^{* *}$ & $-.429^{* *}$ & $.682^{* *}$ & - \\
\hline
\end{tabular}

Note. Strategy $=$ Overall strategy use; Anxiety = Language anxiety; Actual = Actual language proficiency

$* * p<.01$

As a host of studies revealed a positive relation between LLSU and language proficiency (Dreyer \& Oxford, 1996; Green \& Oxford, 1995; Griffiths, 2003; Magogwe \& Oliver, 2007; Peacock \& Ho, 2003; Yilmaz, 2010), learner self-rated proficiency was found to have an even stronger relation with strategy use than actual language proficiency does in the present study. It should be noted that subjects with the highest level of perceived proficiency composed the only group with an average score for overall strategy use in the high-use range based on Oxford's (1990) criterion. In sum, self-perceived competence may serve as a very strong predictor of LLSU. However, the effect of language anxiety on language learning cannot be ignored as it can have a similar level of correlation with LLSU as actual language proficiency does.

Finally, while MacIntyre and Noels (1996) found that language anxiety was only related to LLSU in three categories of strategies, i.e., social (-.40), cognitive (-.24), and metacognitive (-.20), in decreasing order of correlation coefficients, the findings in Table 8 indicated significant negative correlations between language anxiety and LLSU in all six categories. The three strategy categories that had the highest correlations with LLSU matched the ones reported in MacIntyre and Noels's (1996) study, albeit in a different order. The strategy category that had the strongest link with language anxiety was cognitive (-.415), followed by metacognitive (-.398) and social (-.396). In addition, self-rated proficiency was also found to be significantly related to LLSU in all six categories. Consistently, the strategy type that showed the strongest correlation with self-rated proficiency was cognitive, followed by metacognitive (.635 and .567 , respectively).

\section{Conclusion and Implications}

The findings of this study offer a fuller understanding of LLSU in relation to foreign language anxiety and self-perceived competence among EFL learners. According to Oxford (1990), learning strategies are "specific actions taken by the leaner to make learning easier, faster, more enjoyable, more self-directed, more effective, and more transferrable to new situations" (p. 8). Indeed, fostering appropriate use of learning strategies and further increasing the frequency of strategy use are essential if students are to become more independent and effective learners. As the main findings revealed significant relations between strategy use frequency, foreign language anxiety, and self-evaluation of competence, some important implications should be noted.

First, in general, regardless of anxiety levels, metacognitive, compensation, and cognitive strategies were the three most used types of strategies, with memory and social strategies being the two least used strategy types. However, language anxiety seems to result in a greater effect on variation among frequency of strategy use than on preferences or choices of strategy types by the EFL learners. Strategy use frequency among students susceptible to high levels of anxiety was found to be significantly lower than that of those in other levels.

Second, the effect of anxiety on language learning is undeniably significant and cannot be ignored. In the present study, language anxiety was found to have a similar level of association with LLSU as actual language proficiency does. In addition, its level of correlation with perceived proficiency is comparable to that between perceived and actual proficiency, except that anxiety has a negative impact on the other studied variables while 
the impact of actual language proficiency is positive. The adverse relationship between anxiety and perceived competence has also been noted by MacIntyre and Charos (1996) and MacIntyre, Noels, and Clément (1997). MacIntyre et al. (1997) postulated that anxiety may cause language learners to make errors regarding the evaluation of their own performance. In fact, highly anxious learners are very likely to underestimate their language proficiency. More efforts and attention are needed by language instructors to help students prone to higher anxiety levels cope with its potentially debilitating effects.

Third, affective strategies, which can be applied to help learners lower their anxiety and feel encouraged (Oxford, 1990), were the second least used strategy type after social strategies among the EFL learners in this study. Students in the high-anxiety level seldom employed affective strategies; similarly, the use of affective strategies by those with low perceived ability level was also in the low-frequency range. Utilization of affective strategies has not seemed to receive as much attention as metacognitive or cognitive strategies from researchers, instructors, or even students in the past. An awareness and use of affective strategies should be fostered among language students, particularly if they are identified as anxious learners, as this type of strategies may help them better control their emotional states and sustain motivation to learn.

Finally, perceived competence plays an influential role in enhancing language learning. The positive link between objective language performance and LLSU has been shown in a number of studies (Griffiths, 2003; Lai, 2009; Magogwe \& Oliver, 2007; Peacock \& Ho, 2003). The findings that self-rated competence was a better predictor of LLSU than actual proficiency and it was positively related to strategy use in all six categories supported the notion reported by Oxford and Nyikos (1989) and Lee and Oxford (2008) that self-rated proficiency is one potent factor on strategy use. Dörnyei (2001) proposed that one useful motivational strategy in the language classroom is to encourage positive self-evaluation. Language instructors should treat students with greater patience, particularly encouraging those with underachieving performance to attribute their unsatisfactory achievements to the inappropriate use of learning strategy or lack of effort rather than academic incompetence.

\section{References}

Aida, Y. (1994). Examination of Horwitz, Horwitz, and Cope's construct of foreign language anxiety: The case of students of Japanese. The Modern Language Journal, 78(2), 155-168. http://dx.doi.org/10.1111/j.1540-4781.1994.tb02026.x

Chamot, A. U. (2005). Language learning strategy instruction: Current issues and research. Annual Review of Applied Linguistics, 25, 112-130. http://dx.doi.org/10.1017/S0267190505000061

Chan, D. Y. C., \& Wu, G. C. (2004). A study of foreign language anxiety of EFL elementary school students in Taipei county. Journal of National Taipei Teachers College, 17(2), 287-320.

Chen, M. M.-H. (2007). Language learning strategies and English proficiency of Taiwan language college students. Languages, Literary Studies and International Studies: An International Journal, 4, 49-72.

Chen, K. T., \& Jonas, A. M. (2009). Understanding Taiwanese College Students' Strategies for English Language Learning. Chaoyang Journal of Humanities and Social Sciences, 7(1), 97-130.

Cheng, Y.-S. (2004). EFL students' writing anxiety: Sources and Implications. English Teaching \& Learning, 29(2), 41-62.

Crookes, G., \& Schmidt, R. W. (1991). Motivation: Reopening the research agenda. Language Learning, 41(4), 469-512. http://dx.doi.org/10.1017/S0267190505000061

Dreyer, C., \& Oxford, R. L. (1996). Learning strategies and other predictors of ESL proficiency among Afrikaans speakers in South Africa. In R. L. Oxford (Ed.), Language learning strategies around the world: Cross-cultural perspectives (Technical Report \#13) (pp. 61-74). Honolulu: University of Hawaii, Second Language Teaching \& Curriculum Center.

Dörnyei, Z. (2001). Motivational strategies in the language classroom. Cambridge, UK: Cambridge University Press. http://dx.doi.org/10.1017/CBO9780511667343

Green, J. M., \& Oxford, R. L. (1995). A closer look at learning strategies, L2 proficiency, and gender. TESOL Quarterly, 29(2), 261-297. http://dx.doi.org/10.2307/3587625

Gregersen, T., \& Horwitz, E. K. (2002). Language learning and perfectionism: Anxious and non-anxious language learners' reactions to their own oral performance. The Modern Language Journal, 86(4), 562-570. http://dx.doi.org/10.1111/1540-4781.00161

Griffiths, C. (2003). Patterns of language learning strategy use. System, 31, 367-383. 
http://dx.doi.org/10.1016/S0346-251X(03)00048-4

Horwitz, E. K., Horwitz, M. B., \& Cope, J. (1986). Foreign language classroom anxiety. The Modern Language Journal, 70(2), 125-132. http://dx.doi.org/10.1111/j.1540-4781.1986.tb05256.x

Hsiao, T.-Y., \& Oxford, R. L. (2002). Comparing theories of language learning strategies: A confirmatory factor analysis. The Modern Language Journal, 86(3), 368-383. http://dx.doi.org/10.1111/1540-4781.00155

Jen, C.-Y. (2003). Anxiety in English language classrooms: An investigation of Taiwanese secondary school students' foreign language anxiety in four classroom contexts. Unpublished master thesis, University of Bristol.

Kim, S. Y. (2009). Questioning the stability of foreign language classroom anxiety and motivation across different classroom contexts. Foreign Language Annals, 42(1), 138-157. http://dx.doi.org/10.1111/j.1944-9720.2009.01012.x

Krashen, S. D. (1987). Principles and practice in second language acquisition. Englewood Cliffs, NJ: Prentice-Hall International.

Krashen, S. D. (1989). Language acquisition and language education. UK: Prentice Hall International.

Lai, Y.-C. (2009). Language learning strategy use and English proficiency of university freshmen in Taiwan. TESOL Quarterly, 43(2), 255-280.

Lan, R., \& Oxford, R. L. (2003). Language learning strategy profiles of elementary school students in Taiwan. IRAL, 41, 339-379. http://dx.doi.org/10.1515/iral.2003.016

Lee, K. R., \& Oxford, R. L. (2008). Understanding EFL learners' strategy use and strategy awareness. The Asian EFL Journal, 10(1), 7-32.

Liu, H. J. (2010a). Motivation to learn in the ability-grouped foreign language classroom. Taipei: Crane Publishing Co., Ltd.

Liu, H. J. (2010b). Foreign language anxiety in university classes: A study of its relationship with English reading performance. Providence Forum: Language and Humanities, 4(1), 173-194.

Macaro, E. (2006). Strategies for language learning and for language use: Revising the Theoretical Framework. The Modern Language Journal, 90(3), 320-337. http://dx.doi.org/10.1111/j.1540-4781.2006.00425.x

MacIntyre, P. D. (1999). Language anxiety: A review of the research for language teachers. In D. J. Young (Ed.), Affect in foreign language and second language learning: A practical guide to creating a low-anxiety classroom atmosphere. Boston: McGraw-Hill College.

MacIntyre, P. D., \& Charos, C. (1996). Personality, attitudes, and affect as predictors of second language communication. Journal of Language and Social Psychology, 15(1), 3-26. http://dx.doi.org/10.1177/0261927X960151001

MacIntyre, P. D., \& Gardner, R. C. (1989). Anxiety and second-language learning: Toward a theoretical clarification. Language Learning, 39(2), 251-275. http://dx.doi.org/10.1111/j.1467-1770.1989.tb00423.x

MacIntyre, P. D., \& Gardner, R. C. (1991a). Methods and results in the study of anxiety and language learning: A review of the literature. Language Learning, 41(1), 85-117. http://dx.doi.org/10.1111/j.1467-1770.1991.tb00677.x

MacIntyre, P. D., \& Gardner, R. C. (1991b). Language anxiety: Its relationship to other anxieties and to processing in native and second languages. Language Learning, 41(4), 513-534. http://dx.doi.org/10.1111/j.1467-1770.1991.tb00691.x

MacIntyre, P. D., \& Gardner, R. C. (1994). The subtle effects of language learning on cognitive processing in the $\begin{array}{llll}\text { second language. Language 283-305. } & \end{array}$ http://dx.doi.org/10.1111/j.1467-1770.1994.tb01103.x

MacIntyre, P. D., \& Noels, K. A. (1996). Using social-psychological variables to predict the use of language learning strategies. Foreign Language Annals, 29(3), 373-386. http://dx.doi.org/10.1111/j.1944-9720.1996.tb01249.x

MacIntyre, P. D., Noels, K. A., \& Clément, R. (1997). Biases in self-ratings of second language proficiency: The $\begin{array}{lllll}\text { role of language anxiety. Language } & \text { Learning, }\end{array}$ http://dx.doi.org/10.1111/0023-8333.81997008 
Magogwe, J. M., \& Oliver, R. (2007). The relationship between language learning strategies, proficiency, age and self-efficacy beliefs: A study of language learners in Botswana. System, 35, 338-352. http://dx.doi.org/10.1016/j.system.2007.01.003

Marcos-Llinás, M., \& Garau, M. J. (2009). Effects of language anxiety on three proficiency-level courses of Spanish as a foreign language. Foreign Language Annals, 42(1), 94-111. http://dx.doi.org/10.1111/j.1944-9720.2009.01010.x

McMullen, M. G. (2009). Using language learning strategies to improve the writing skills of Saudi EFL students: Will it really work? System, 37, 418-433. http://dx.doi.org/10.1016/j.system.2009.05.001

Nyikos, M., \& Oxford, R. L. (1993). A factor analytic study of language-learning strategy use: Interpretations from information-processing theory and social psychology. The Modern Language Journal, 77(1), 11-22. http://dx.doi.org/10.1111/j.1540-4781.1993.tb01940.x

Onwuegbuzie, A. J., Bailey, P., \& Daley, C. E. (1997). Foreign language anxiety among college students. Paper presented at the annual conference of the Mid-South Educational Research Association, Memphis, TN. (ERIC DOC ED 415 713).

Onwuegbuzie, A. J., Bailey, P., \& Daley, C. E. (1999). Factors associated with foreign language anxiety. Applied Psycholinguistics, 20, 217-239. http://dx.doi.org/10.1017/S0142716499002039

Oxford, R. L. (1990). Language learning strategies: What every teacher should know. Boston, MA: Heinle \& Heinle.

Oxford, R. L. (1999). "Style wars" as a source of anxiety in language classrooms. In D. J. Young (Ed.), Affect in foreign language and second language learning. Boston: McGraw-Hill College.

Oxford, R. L., \& Ehrman, M. E. (1995). Adults' language learning strategies in an intensive foreign language program in the United States. System, 23(3), 359-386. http://dx.doi.org/10.1016/0346-251X(95)00023-D

Oxford, R. L., \& Nyikos, M. (1989). Variables affecting choice of language learning strategies by university students. Modern Language Journal, 73(2), 291-300. http://dx.doi.org/10.1111/j.1540-4781.1989.tb06367.x

Peacock, M., \& Ho, B. (2003). Student language learning strategies across eight disciplines. International Journal of Applied Linguistics, 13(2), 179-195. http://dx.doi.org/10.1111/1473-4192.00043

Phillips, E. M. (1992). The effects of language anxiety on students' oral test performance and attitudes. The Modern Language Journal, 76(1), 14-26. http://dx.doi.org/10.1111/j.1540-4781.1992.tb02573.x

Rubin, J. (1975). What the "good language leaner" can teach us. TESOL Quarterly, 9(1), 41-51. http://dx.doi.org/10.2307/3586011

Rubin, J. (1987). Learner strategies: Theoretical assumptions, research history and typology. In A. Wenden, \& J. Rubin (Eds.), Learner strategies in language learning (pp.15-30). Englewoods Cliffs, NJ: Prentice Hall.

Saito, Y., Horwitz, E. K., \& Garza, T. J. (1999). Foreign language reading anxiety. The Modern Language Journal, 83(2), 202-218. http://dx.doi.org/10.1111/0026-7902.00016

Saito, Y., \& Samimy, K. K. (1996). Foreign language anxiety and language performance: A study of learner anxiety in beginning, intermediate, and advanced-level college students of Japanese. Foreign Language Annals, 29(2), 239-251. http://dx.doi.org/10.1111/j.1944-9720.1996.tb02330.x

Sánchez-Herrero, S. A., \& Sánchez, M. D. P. (1992). The predictive validation of an instrument designed to measure student anxiety in learning a foreign language. Educational and Psychological Measurement, 52, 961-966. http://dx.doi.org/10.1177/0013164492052004019

Sheu C.-M. (2009). An investigation into English Learning Strategies of Ability-Grouped Freshman Students in a National Technological University. Studies in English Language and Literature, 23, 23-39.

Wang, S. (2010). An experimental study of Chinese English major students' listening anxiety of classroom learning activity at the university level. Journal of Language Teaching and Research, 1(5), 562-568. http://dx.doi.org/10.4304/jltr.1.5.562-568

Wei, M. (2007). The interrelatedness of affective factors in EFL learning: An examination of motivational patterns in relation to anxiety in China. TESL-EJ, 11(1), 1-23.

Wharton, G. (2000). Language learning strategy use of bilingual foreign language learners in Singapore. Language Learning, 50(2), 203-243. http://dx.doi.org/10.4304/jltr.1.5.562-568 
Williams, K. E., \& Andrade, M. R. (2008). Foreign language learning anxiety in Japanese EFL university classes: Causes, coping, and locus of control. Electronic Journal of Foreign Language Teaching, 5(2), 181-191.

Wu, H. J. (2011). Anxiety and reading comprehension performance in English as a foreign language. Asian EFL Journal, 13(2), 273-307.

Yan, J. X., \& Detaramani, C. (2008). A comparison of language anxiety in English and Mandarin learning in Hong Kong. English Teaching \& Learning, 32(1), 45-85.

Yan, J. X., \& Horwitz, E. K. (2008). Learners' perceptions of how anxiety interacts with personal and instructional factors to influence their achievement in English: A qualitative analysis of EFL learners in China. Language Learning, 58(1), 151-183. http://dx.doi.org/10.1111/j.1467-9922.2007.00437.x

Yang, N.-D. (1992). Second language learners' beliefs about language learning and their use of learning strategies: A study of college students of English in Taiwan (Doctoral dissertation). University of Texas at Austin.

Yang, N.-D. (1999). The relationship between EFL learners' beliefs and learning strategy use. System, 27, 515-535. http://dx.doi.org/10.1016/S0346-251X(99)00048-2

Yilmaz, C. (2010). The relationship between language learning strategies, gender, proficiency and self-efficacy beliefs: A study of ELT learners in Turkey. Procedia Social and Behavioral Sciences, 2, 682-687. http://dx.doi.org/10.1016/j.sbspro.2010.03.084

Yin, C. (2008). Language learning strategies in relation to attitudes, motivation, and learner beliefs: Investigation learner variables in the context of English as a foreign language in China (Doctoral dissertation). University of Maryland at College Park.

Young, D. J. (1990). An investigation of students' perspectives on anxiety and speaking. Foreign Language Annals, 23(6), 539-553. http://dx.doi.org/10.1111/j.1944-9720.1990.tb00424.x

Young, D. J. (1991). Creating a low-anxiety classroom environment: What does language anxiety research $\begin{array}{lllll}\text { suggest? } & \text { The } & \text { 426-439. }\end{array}$ http://dx.doi.org/10.1111/j.1540-4781.1991.tb05378.x

Young, D. (1992). Language anxiety from the foreign language specialist's perspective: Interviews with Krashen, Omaggio Hadley, Terrell, and Rardin. Foreign Language Annals, 25(2), 157-172. http://dx.doi.org/10.1111/j.1944-9720.1992.tb00524.x

Young, D. J. (Ed.) (1999). Affect in foreign language and second language learning. Boston: McGraw-Hill College. 